Historic, Archive Document

Do not assume content reflects current scientific knowledge, policies, or practices. 


\section{THE HANDY Catalogue}

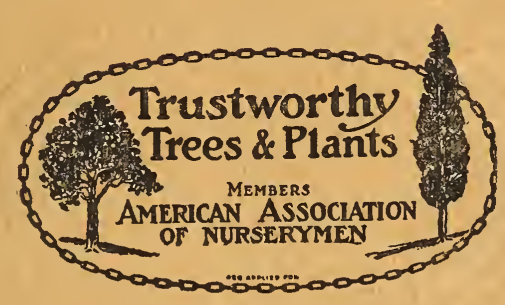

TEXAS NURSERY C0. SHERMAN, TEXAS 
APPLES

Page

APRICOTS

11-12

BLACKBERRIES

8

15-16

BULBS.

28-29-30-31

CHERRIES.

12-13

CLIMBING VINES.

24-25

CRAB APPLES.

CURRANTS.

DEWBERRIES

EVERGREENS

25-26-27

FIGS 16

GOOSEBERRIES.

GRASSES.

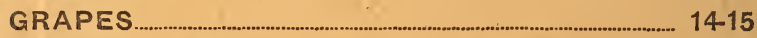

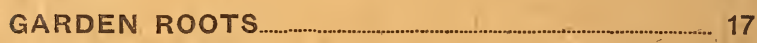

HEDGE PLANTS.

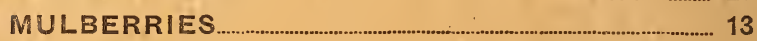

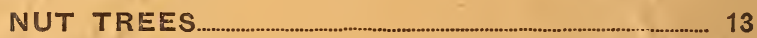

ORNAMENTALS

PEACHES ........................................................................... 45-6

PEARS.

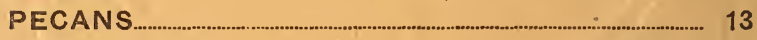

PERENNIALS...………………………................................. 28-29-30-31

PERSIMMONS............................................................................ 8

PLUMS.......................................................................................... 9-10



RASPBERRIES.................................................................................. 17

ROSES.

SHRUBS...................................................................... 20-21-22-23-24

SHADE TREES

STRAWBERRIES......................................................................... 17

VINES

WALNUT-Black

\section{DISTANCES TO PLANT}

On good average soil trees should be planted: Apples, 30 by 20 feet, 69 trees to the acre; Peaches, 20 by 20 feet, 108 trees to the acre; Plums, Prunes, Apricots and Cherries, 18 by 18 feet, 134 trees to the acre; Figs and Japan Persimmons, 15 by 15 feet, 193 trees to the acre; Oranges, 18 by 18 feet, 134 trees to the acre; Kumquats, 12 by 12 feet, 300 trees to the acre; Japan and English Walnuts, 30 by 30 feet, 48 trees to the acre; Street Trees, 15 to 25 feet apart; Grape rows 9 feet apart and 8 feet apart in the row, 605 plants to the acre; Blackberries and Raspberries 8 by 2 feet, 2730 plants to the acre; Dewberries 6 by 3 feet, 2500 plants to the acre; Strawberries 4 by 2 feet, 5400 to the acre; Asparagus 4 by 2 feet, 5400 plants to the acre.

\section{EXPLANATION OF PRICES}

Where as many as six trees are ordered you may figure them at dozen rates, and where fifty or more trees are purchased, figure them at hundred rates. 


\section{THE HANDY CATALOGUE}

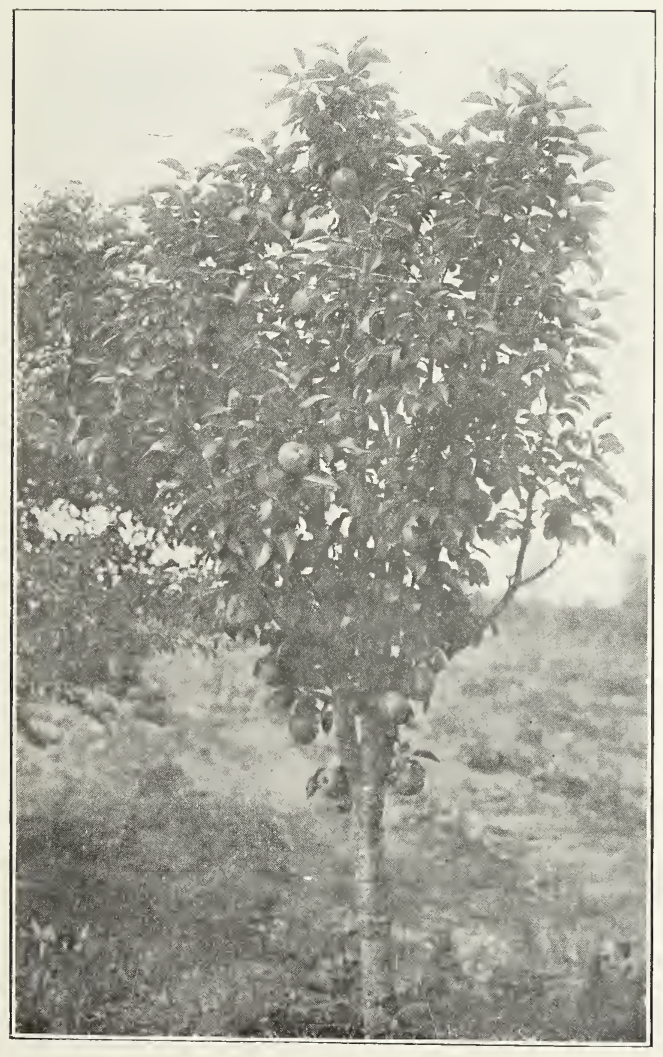

TEXAS NURSERY COMPANY

SHERMAN, TEXAS 


\section{A Little Talk With Our Patrons}

If you are an old friend, all right, howdy do. We are mighty glad to meet with you again and hope to meet you many times in the years to come. Whether you are an old friend, a new comer or have not met us before, the following little talk will help us to get better acquainted.

We have a large catalogue much larger than this one but while it looks simple enough to a man who has studied nothing but trees all his life, we have found that it is confusing to the average man or woman who wants to select a good home orchard. It has listed a large number of varieties alphabetically arranged all with elaborate discriptions but when you have read all of them, you are at a loss which to plant as there is nothing to guide you in the selection of the very best.

Since making this discovery, we have put ourselves in your place and worked out this small catalogue and the accompanying order sheet which we are sure will make it easy for you to make up an order for just what you want and to feel sure that you are making no mistake as to varieties.

The varieties printed in large type in this catalogue and listed on the order sheet are among the very best varieties that have ever been grown for the Southwest. We have tried them under every condition and they have stood the test.

We want you for one of our friends, the kind who will tell your neighbors ${ }^{2} \mathrm{o}$ write us for a catalogue and we know that if you buy trees from the list of our specially recommended varieties, we will be safe in listing your name among our permanent friends. We recommend every variety listed in the catalogue, but our preference is for those in large type, and listed on the order sheet.

When your order is shipped, we will mail you free of charge a little booklet telling you just how to handle, prune, plant and care for your orchard.

Of course we have to make a living out of our business, but we are doing a lot besides making a living. We are helping to make this a better world to live in, and the expressions of appreciation that come from our customers and friends give us a great deal more pleasure than the small profit we make from our sales.

If we should make a mistake in filling your order, which we sometimes do in handling such a large volume of business we hope you will not fail to notify us at once, so that we can correct it. Our errors are few, but you know the fellow who makes no mistakes at all is the fellow who does nothing at all. 


\section{TO AVOID MISUNDERSTANDINGS}

Shipping-We begin shipping stock about November 1st, and continue until about the following March.

Our Digging Is Done with the latest improved tree diggers, labeling, handling and packing with utmost care, using the best packing material and packing in burlaps or boxes.

We Follow Shipping Directions of purchaser as far as possible, and when directions are not given, we follow our best judgment and assume no risk which belongs to purchaser.

Guarantee of Genuineness-We use constant care in keeping everything true to name and description.

Mistakes Are Avoided every possible way, but when they do occur, and when we are promptly notified of such mistakes on receipt of shipments, we gladly correct them, and if any stock proves not true to name, we will replace it with the genuine or return the price paid for same, but it is mutually agreed between ourselves and our purchasers that we are not to be held liable to pay any more than the original price received for the goods.

Location-Our main office and packing grounds are at the South end of Walnut street in South Sherman. Take south bound Travis street cars to end of line and walk one block east and two blocks south.

Whole Roots are secured on our stock by planting best seeds on richest soils, giving most careful cultivation, grafting, or budding, training and handling in the best approved way.

Insects and diseases are almost unknown on trees grown on this rich limestone soil.

Our Prices are based upon cost of production and upon a reasonable profit, and are not in competition with cheap stuff grown in a cheap way.

Reference as to our standing is made to Bradstreet, Dun and to any bank in Sherman, Texas.

Telegrams promptly transmitted to or from our office by phones.

Terms cash.

Money should be sent by Postal or Express money orders, Bank exchange or Registered letter.

For Orders Amounting to Five Dollars and over we pay transportation charges to your railroad station. in Texas, Oklahoma and Louisiana.

With full appreciation of this opportunity of offering you our service, we desire to subscribe ourselves

Your friend as well as servant,

TEXAS NURSERY COMPANY,

Sherman. Texas. 


\section{PEACHES}

The peach is queen of fruits. Its rich and unsurpassed flavor, delicious sweets and acids, beautiful and gorgeous tints and colors, graceful shapes and forms, make it the universal favorite.

This list should be preserved and used in order to identify and study each variety, thus enabling each planter to rightly determine the best varieties for his locality.

\section{Peaches-Specially recommended.}

Listed in order of their ripening. Dates of ripening are reckoned for North Texas. Make due allowances according to distance North or South from Sherman also according to altitudes.

\section{MAY}

Togo-Earliest of all. Very prolific, Red Cheek, white flesh, semi cling of good quality, one of our trade marked varieties.

\section{JUNE}

May Lee-Large beautiful white and red cling, oblong, juicy, good, our introduction, no home orchard is complete without it.

Mikado-The earliest yellow; semi-free, good quality, rather tender for shipping; a splendid home variety. Originated by Mr. E. W. Kirkpatrick, of McKinney, Texas.

Arp Beauty-Yellow with bright blush, a firm, juicy and excellent peach of unusually good flavor, semi cling.

Mamie Ross-One of the most widely planted of the white peaches in the South. It is extremely hardy and very productive. Semi cling, cream colored often marked with red. Ships well if picked before fully ripe. Flesh tinged red near seed, tender juicy and sweet, fine quality.

\section{JULY}

Carman-A white freestone of good quality and large size, ripening first half of July; fine both as a commercial peach and for home use.

Belle of Georgia-One of the very best white peaches for home and commercial planting. Freestone of splendid quality and delicious flavor, very large and showy.

Hobson-Large, red cheeked showy cling, of excellent quality, firm, a good shipper. Tree, very vigorous and a heavy bearer.

Elberta-The most widely known of all peaches. Very attractive in appearance. Large size, deep yel- 
low, splashed crimson, perfect freestone, ripens last half July. Tree very vigorous and highly productive.

Leona-Large yellow freestone similar to Elberta, but better quality, surer bearer and more prolific.

Texan-Very large, white cling with decided blush, a very handsome peach and quite an acquisition. Ripens with Elberta, originated at Whitesboro, Texas, in yard of First National Bank.

Minnie Stanford-Large yellow cling, firm sweet. very prolific. No orchard complate without this splendid peach.

\section{AUGUST}

Family Favorite-A Texas seeding of Chinese Cling, medium size, red cheek, white skin and flesh, juicy and exceptionally good flavor, freestone ripens last July to first August.

Eureka-One of the most hardy peaches. White freestone, very large, delicious flavor and as beautiful as a peach can be, a "sun-kissed beauty." The tree is vigorous, a heavy, regular bearer and a good shipper. Last July to first August.

Old Mixon Cling-Large round, white with distinct red blush, flesh white, red next seed, firm and of excellent quality, adapted to nearly all sections where peaches are grown.

Heath Cling-An old favorite, large, creamy white, thin skin, white flesh, very firm. Fine for preserves and pickles.

e Indian Cling-This is one of the oldest varieties we know, but still holds its place as king of its type. A fine large peach, red skin and flesh, juicy, very hardy and of good quality. We hope it will never disappear from the home orchard.

Augbert-A superb freestone, similar to Elberta but later and in many respects superior. Tree vigorous and prolific, very valuable.

Salway-One of the best and most reliable late peaches, large size freestone, yellow with brownish red cheek, flesh deep yellow, excellent flavor very abundant bearer. Succeeds over a wide range. Another chance to fill your fruit jars.

\section{SEPTEMBER}

Ponds Late-Large roundish oblong, yellow freestone, flesh yellow, quality best. Very productive and reliable. A firm late home and market peach. Ripe in September, originated by our President Mr. E. W. Kirkpatrick-Good canner.

Henrietta-A large yellow cling, shaded red, flesh yellow, firm juicy and sweet. 
Krummels-One of the best late freestone peaches, a splendid shipper and keeps well, large, almost round, deep yellow with red blush. It is not only popular, because of its beauty, but it is of splendid quality, fine texture and free from bitterness. It bears very young and the tree is extremely hardy. It grows well in all sections. Last chance to fill up empty jars.

\section{OCTOBER}

Stinsons Oct.-One of the very few October peaches that is reliable and of good quality. Large, oblong, white with red cheek, good flavor, clingstone. Last call for sweet pickles.

\section{PEACHES: OTHER VARIETIES WHICH WE GROW AND RECOMMEND}

\section{MAY}

VIC'TOR-Cling, red cheek, flesh white.

- MAYFLOWER-Cling, red, flesh white.

- EARLY WHEELER-Cling, red cheek, white flesh, the best early commercial peach.

\section{JUNE}

v. ROGERS-Semi cling, large pointed red cheek.

EARLY ELBERTA-Freestone, yellow.

SLAPPY-Freestone, rellow.

\section{JULY}

LUTON-Cling. large rellow, of fine quality. Good for sweet pickles or preserving.

GENERAL LEE-Cling, large carmine red, white flesh, rery fine.

CHINESE CLING-Very large, red cheek, white flesh, Red next secu, juicy and fine.

\section{AUGUST}

CHILOW CLING-Large rellow, rich, juicr, firm, sure.

CAMEO-Freestone, rellow skin and flesh, best quality.

ELBERTA CLING A fine rellow cling, resembling isluerta. PALESTINE-Cling, sellow with red flesh.

\section{SEPTEMBER}

MURPHY-Cling, sellow.

LATE ELBERTA-Freestone, large oblong, yellow rich, sure.

\section{COAST PEACHES}

\section{JUNE}

JAPAN DIVARF BLOOD-Medinm, deep red, prolific, excellent freestone.

WALDO-Freestone, red, sweet fine flavor.

BEST JUNE-Semi cling, similar to Mamie Ross.

PALLAS-Honey type freestone sweet, creamy color with blush.

\section{JULY}

HONEY-Freestone, medium, oblong, pointed, creamy with red blush, sweet.

ONDERDONK-Freestone, sellow skin and flesh excellent.

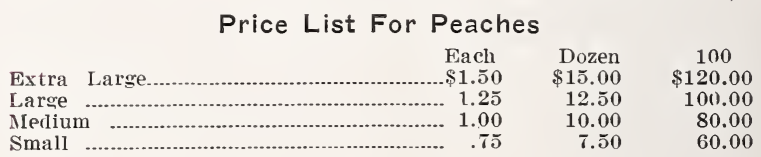




\section{PEARS}

Pears are growing in popularity since the introduction of hardy, prolific varieties, and since we have learned to gather the matured fruit and store and ripen under cover.

The following list of varieties are chosen for their hardiness and placed in about their order of ripening:

Pears-Specially recommended.

\section{JUNE AND JULY}

Early Ely-Small, deep yellow, finest quality for table and market. Trade marked.

Wilder-Small to medium, bell shaped, fine grained tender and juicy, greenish yellow, red cheek, tree hardy and bears young and aburidantly.

\section{AUGUST}

Garber-Large, yellow, with red cheek, keeps remarkably well, and a good shipper-one of the very best for the South.

Duchess-Large, yellow, bell shaped, juicy and tender when ripe, fine flavor. Very popular for home use.

\section{SEPTEMBER}

Kieffer-The best known pear, very large, yellow, thrives under all climates and conditions-should be gathered and ripened in storage. Tree very vigorous, resisting blight. Very productive. Garber should be planted with Kieffer to insure best pollenizing.

Pears-Other varieties which we grow and recommend.

\section{JUNE}

ALAMO-Texas seedling of Bartlett, but earlier, smaller and sweeter.

\section{JULY}

BARTLETT-A well known pear of fine flavor, very popular for table use.

CLAPPS FAVORITE-Very large yellow-Summer pear, good quality.

FLEMISH BEAUTY-Pale yellow covered red russet, large, melting sweet.

LECONTE-Large bell shaped, smooth, rich, bears young, more subject to blight than Kieffer.

MAGNOLIA-Beautiful yellow russet, globular, large showy.

SECKEL-Small, delicious flavor, brownish green, with russet cheek.

\section{Prices For Pear Trees}

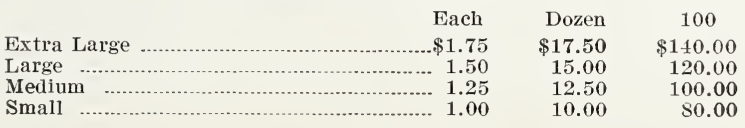




\section{APRICOTS RECOMMENDED}

This delightful fruit should be planted on most elevated places or near buildings where they will be partially protected from late frost or severe and sudden changes in temperatures. Valuable in semiarid districts.

The following list of select varieties are arranged in about the order of their time of ripening.

CLUSTER-Medium, golden, yellow of excellent flavor, originated in Texas.

EARLY GOLDEN-Medium, yellow, freestone, rich, juicy, good slavor, originated by Mr. E. W. Kirkpatrick, McKinney, 'Texas.

LAMPASAS-Of Texas origin, large yellow with red check, quality good.

MOORPARK-Large, yellowish green, brownish red an sunny side, marked with dark specks. Freestone, good for canning and drying. Tree vigorous and productive.

ROYAL-A European variety, large, slightly oval, dall yellow, rich flavor.

TOYAHVALE-A remarkable Russian Seedling, originated by Mr. C. W. Giffin at Toyahvale, Texas. Blooms very late, hence a safe bearer, fruit medium size, yellow, fine flavor, bears abundantly.

\begin{tabular}{|c|c|c|c|c|}
\hline & Prices For & Apricots & & \\
\hline & & Each & Dozen & 100 \\
\hline Extra Large & & $\$ 1.75$ & $\$ 17.50$ & $\$ 140.00$ \\
\hline Large $\ldots . . . . . . . . .$. & 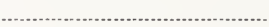 & 1.50 & 15.00 & 120.00 \\
\hline Medium ........ & (1) & 1.25 & 12.50 & 100.00 \\
\hline Small & & 1.00 & 10.00 & 80.00 \\
\hline
\end{tabular}

\section{JAPAN PERSIMMONS}

This royal fruit from Japan is deservedly popular, most beautiful in foliage and fruit, and the most delicious of all fruits. It gains in the estimation of people everywhere when they learn its value. We offer best obtainable varieties grafted on native stocks.

KURO KUME-Large, round, dark red skin and flesh, very productive, ripe in October.

MINO-Large, oblong pointed, bright red, hardy, productive, ripe in November.

TANE-NASHI-Very large, light yellow changing to bright red, flesh yellow, seedless, very fine, November.

YEMION-Large flat, tomato shaped, very prolific and very fine quality, October.

\section{Prices For Japan Persimmons}

\begin{tabular}{|c|c|c|c|}
\hline & Each & Dozen & 100 \\
\hline Medium & $\ldots 1.75$ & $\$ 17.59$ & $\$ 1+0$ \\
\hline
\end{tabular}




\section{PLUMS}

The plum is easily grown, adapts itself to widely varying conditions, and will succeed anywhere that trees will grow.

Plums-Specially recommended, listed about in the order of ripening.

\section{JUNE}

Six Weeks-The earliest of all plums, large oblong, bright red, flesh pink, seed small. Tree vigorous and prolific. Grows well in all sections of the Southwest.

Francis-Originated by Mrs. Francis Johnson, of Denison, Texas, trade-marked by us. A yellow plum, of large size and high quality; very prolific; strong grower; one of the best.

\section{JULY}

America-Successful everywhere. Bears young and abundantly. This plum should be in every orchard or back yard, a beautiful golden yellow with red cheek.

Burbank-A well known large Japanese plum and one of the most popular in all sections, richly colored red mottled and dotted yellow. A very heavy bearer.

Shiro-One of the finest in quality, delicious for eating out of hand, sweet and splendid flavor, pale yellow, beautiful in appearance.

Milton-Large, round, deep red-A valuable variety for the home orchard and profitable for marketing, blooms late and is highly productive.

\section{AUGUST}

Pooles Pride-Tree very hardy and bears abundantly, light crimson fruit with delicate bloom, splendid for cooking and preserving.

Eagle-A very prolific plum, small, bright red, juicy, fine for preserves. Tree vigorous and grows anywhere.

\section{SEPTEMBER}

Reagan-A medium sized red plum, a vigorous grower, blooms late, one of the best plums for cooking, preserving and jelly. Trade marked by us.

Golden Beauty-An old favorite, medium size, yellow, fine for jelly and preserves, very heavy bearer.

Irby September-A very popular late plum, medium size, red when ripe. Very valuable for home or market. 
Plums-Other varieties grown and recommended.

\section{JUNE}

ABUNDANCE-BOTAN-One of the most reliable bearers, large size, cherry red, firm and sweet.

GONZALES-Large, brilliant red, very productive-originated in Texas.

RED JUNE-A popular early plum, dark red, showy, good quality, a sure bearer.

WILD GOOSE-An old well known variety, merium size, red skin, yellow ground, good for jelly.

\section{JULY}

WICKSON-One of the largest in size, heart shaped, red skin, flesh yellow, melting, and good.

\section{AUGUST}

GERMAN PRUNE-Medium, dark purpie, successful wherever prunes are grown.

FRENCH PRUNE-Medium, purple, sweet, grown extensively in California.

Prices For Plums

\begin{tabular}{|c|c|c|c|}
\hline & Each & Dozen & 100 \\
\hline Extr & $\$ 1.75$ & $\$ 17.50$ & $\$ 140.00$ \\
\hline & $\ldots 1.50$ & 15.00 & 120.00 \\
\hline & 1.25 & 12.50 & 100.00 \\
\hline 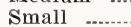 & 1.00 & 10.00 & 80.00 \\
\hline
\end{tabular}




\section{APPLES}

Apples are pre-eminently the fruit of commerce, being more widely and more extensively grown than any other fruit. Apple orchards are proving very valuable in many sections in Texas. The Southern planter should adhere closely to those varieties which have proven most valuable in the South.

The following list contains varieties which have proven successful in Texas. Listed about in order of their ripening.

Apples-Specially recommended.

\section{EARLY SUMMER}

Yellow Transparent-Widely and favorably known, large size, transparent yellow, crisp, subacid, very fragrant, excellent cooker, tender, bears young, tree dwarfish, very hardy.

Red June-One of the best early apples for table and market, medium deep red, flesh white, crisp, very fine.

Early Harvest-Bright straw yellow, tender, subacid, fine dessert and cooking apple, must be handled very carefully for market, fine for home use.

San Jacinto-Large, red, very productive, fine quality. Has long period of bearing, and is very reliable.

\section{LATE SUMMER}

Red Astrachan-Medium, flat, deep crimson, flesh white, moderately juicy, acid flavor, very productive.

Bledsoe-A Texas seedling, an apple of great merit for the Southwest. Large roundish, yellow striped red, subacid, very prolific and hardy.

Summer Queen-Large, yellow ground, red stripes, very fine for table or market.

\section{FALL}

Jonathan-The variety that never disappoints, brilliant red, spicy flavor, juicy, splendid for home or market. Bears young, very prolific, don't fail to plant a Jonathan.

Winesap-One of the oldest American Apples and still in favor, medium size, rich red, very best quality and flavor, one of the best keepers, a very popular apple.

Gano-Large roundish oblong, similar to Ben Davis, rich red color. Popular for commercal planting and for home use.

\section{WINTER}

Mammoth Black Twig-Large, yellow, shaded red, flesh pale yellow, tender, juicy, rich. Tree vigorous, very productive.

Delicious-One of the very best for home or market. Large yellowish splashed red, oblong, very tender and melting. Very popular for table, brings highest price on market.

Texas Red-Originated in East Texas. Large, striped, a very valuable keeping apple.

Apples-Other varieties we grow and recommend. 


\section{EARLY SUMMER}

DIXIE-Beautiful yellow, smooth, firm, subacid, good cooking or eating.

COLE-Medium, pale yellow, tender, subacid, good.

INDIAHOMA-Large, oblong, red, good flavor.

TIOGA-Large, oblong, orange overspread with red, good quality, has long continuous period of ripening.

HORSE-Large, oblong, yellow, fine cooking and drying.

OLDENBURG-A Russian apple, large, streaked with red, juicy rich, subacid.

\section{LATE SUMMER}

SMOKEHOUSE-Greenish yellow, a splendid cooking apple.

WETSEL-Large, round, greenish, flesh yellow, firm and good. Grows well on black land.

ROME BEAUTY-An old favorite, good for cooking, striped red, tender, juicy, good.

TEXAS KING-Large, yellowish, splashed with red, juicy, crisp, subacid.

WEALTHY-Medium, smooth, light yellow, shaded red, flesh white, tender, juicy.

\section{FALL}

ARKANSAS BLACK-Dark red, almost black, large, very good appearance, good quality, shy bearer.

BEN DAVIS-Large, yellowish, covered with red, flesh white, mealy. Quality of this apple is better when grown in Southwest than when grown in the East.

GRIMES-Golden vellow, finest quality, a favorite for home and market.

KINNARDS-Deep red on yellow ground, flesh yellow, crisp, juicy, fine flavor.

MISSOURI PIPPIN-Medium, roundish, yellow, splashed with red, tender and good.

SHOCKLEY-Small, round, pale yellow overspread with red, good quality.

YORK IMPERIAL-Red with faint stripes of darker red, good quality crisp, firm, of fine texture.

\section{WINTER}

STAYMAN WINESAP-Very large, beautiful red, flesh yellow, resembles Winesap but larger.

CRAB Apples-Grown and recommended by us:

FLORENCE-Bears very young, very prolific, dwarfish tree, fruit striped crimson and yellow. Good for jelly and preserves.

HYSLOP-Large, dark red, very acid.

TRANSCENDENT-Medium, pleasant flavor, very hardy, yellow partly covered with red.

WHITNEY - Green, splashed with red, flesh firm, juicy, good flavor, very hardy and productive.

\section{Prices For Apples and Crab Apples}

\begin{tabular}{|c|c|c|c|}
\hline Extra Large & $\begin{array}{l}\text { Each } \\
\$ 1.50\end{array}$ & $\begin{array}{r}\text { Dozen } \\
\$ 15.00\end{array}$ & $\begin{array}{c}100 \\
\$ 120.00\end{array}$ \\
\hline Large ........... & 1.25 & 12.50 & 100.00 \\
\hline Medium & $\ldots 1.00$ & 10.00 & 80.00 \\
\hline Small & .75 & 7.50 & 60.00 \\
\hline
\end{tabular}

\section{CHERRIES}

The Cherry thrives best in a cool or Northern climate. A few hardy varieties of acid cherries do moderately well in the South on elevated, rich, dry locations.

Cherries-Specially recommended.

Early Richmond-Medium size, clear red, acid, good quality and reliable.

Montmorency-Large, light red, moderately acid, very productive.

New Century-Originated in Grayson County, Texas. Fruit medium to large, light red, of good quality. Tree vigorous and reliable. Try them.

Compass Or Plum Cherry-A cross between a Miner plum and Cherry. Tree vigorous grower, very 
prolific, hardy and bears extremely young. Fruit black, fine for jelly, pies and preserves.

Cherries-Other varieties we grow.

BALDWIN-Round, red, good flavor.

BLACK TARTARIAN-Large, black, heart shaped, juicy and sweet.

ENGLISH MORELLO-Medium, dark red, dark flesh, acid.

GOVERNOR WOOD-Large, heart shaped, light yellow, marbled red, juicy, rich and sweet.

\begin{tabular}{|c|c|c|c|}
\hline \multicolumn{4}{|c|}{ Prices For Cherries } \\
\hline & Each & Dozen & 100 \\
\hline Extra Large & $\$ 1.75$ & $\$ 17.50$ & $\$ 140.00$ \\
\hline e ... & 1.50 & 15.00 & 120.00 \\
\hline Medium & .... 1.25 & 12.50 & 100.00 \\
\hline Small & 1.00 & 10.00 & 80.00 \\
\hline
\end{tabular}

\section{MULBERRIES}

Mulberries-Specially recommended.

Travis-Fruit of large size; black berries; prolific bearer. T'ree strong grower, very hardy. The best of the fruiting Mulberries.

Hicks Everbearing-Fruits abundantly for several months, June, July and August, fruit large, black, sweet, does well in Southwest.

Black English-Excellent flavor, fruit large, ripe in June, tree hardy and very prolific.

Paper White-Nonbearing. See shade trees.

\begin{tabular}{rrrrrr}
\multicolumn{7}{c}{ Prices For Mulberries } \\
6 \\
6
\end{tabular}

\section{PECANS}

Pecans Grafted-Specially recommended.

Stuart-A standard variety-medium, well shaped, of fine appearance, meaty, thin shell, well flavored.

Schley-Medium, long pointed, very thin shell, meat plump, full, separating easily. Best quality.

Van Deman-Large, oblong, thin shell, cracks and separates well, meat plump, and of good quality.

Delmas-Large, good quality, fills well. One of the best commercial varieties.

Frotscher-Originated in Louisiana. Nuts cylindrical, slightly tapering, shell thin, parting easily from the kernel; of delicate flavor and fine quality.

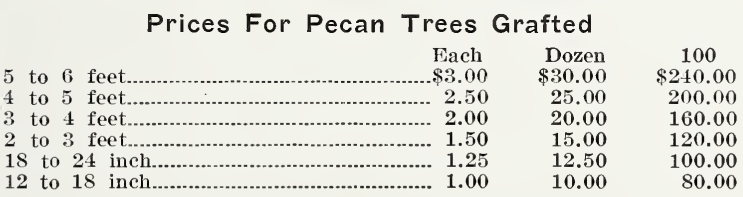

\section{WALNUTS}

BLACK WALNUTS-Recommended for shade and timber.

\section{Prices For Black Walnut}

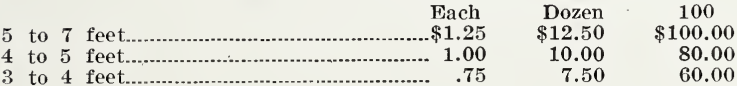




\section{GRAPES}

We give special attention to grape growing. We grow our grapes from our own vineyards. Our plants are grown on fresh, rich land, producing strong vines with a fine root system. They will please you. Our Tree Planter's Guide tells how to grow them best.

Grapes-Specially recommended.

\section{JUNE}

Moore's Early-Very large, early, black of fine quality, fine for market or home, hardy and prolific.

\section{JULY}

Brilliant-Very strong grower, endures Texas climate well, cluster large, berries large, red, translucent very handsome, skin thin and tender, seldom cracks-pulp meaty, but tender, delicious flavor.

Lindley-An exceptionally fine table grape, large red berries, skin tough, plant near Delaware and Brilliant for best results.

Bell-Vine vigorous, hardy, sure bearer, cluster medium, fairly compact, berry medium, round greenish yellow, skin thin, pulp tender, juicy, sweet, good flavor.

Delaware-Small, clear red, of very finest flavor, a standard of excellence among table grapes and market.

Concord-The best known variety, large, black suited for table or market.

\section{AUGUST}

Niagara-Large, greenish white, semi transparent, good quality, successful over wide range of country.

Agawam-Large, bronzy red skin thick pulp, tender, vine vigorous and fairly productive.

R. W. Munson-Medium to large bunch, berry black, does not crack, pulp tender, quality good, should be planted near Concord or Brilliant for pollenizing.

America-Growth very long, good for arbors, berry medium, black; good for wine or table, must have other varieties with it to pollenize.

Carman-One of the most profitable and popular varieties, fine for table or wine, juicy, preserves and jelly. Cluster very large, berries medium, black, skin tough and thin, never cracks, pulp tender.

\section{SEPTEMBER}

Herbemont-Cluster large, berry small, purple, flavor mild, subacid, fine for wine, very prolific. August to September.

Grapes-Other varieties we grow and recommend.

\section{JUNE}

I'RESLEY - Very earls, medium, red, good flavor.

CAMPBELL EARLY-Clusters very large, berry black. A very showy grape of the Concord type and very valuable.

BIG EXTRA-Extra large bunch, berries black of fine quality, a Post Oak hybrid variety, very hardy and prolific.

BLACK SPANISH-Large cluster, small, black berry, does well in Southwest Texas.

CAPTAIN-Cluster very large, long and cylindrical, large black berrs. skin thin, pulp tender, should be planted near other grapes for pollenizing.

CHAMPANEL-Large, black with white bloom, juicy, acid until fully ripe. 
DIAMOND--Large, white of fine quality-one of the best in quality.

GOLD COIN-Medium cluster, large berry, yellowish when fully ripe, juicy and sweet, very prolific.

ROMMEL-Cluster medium, compact, berry medium, round pale yellow, most delightful flavor, liked by all.

WORDEN-Large, black, of Concord type, ripening earlier than Concord.

\section{AUGUST}

ELLEN SCOTT-Vine vigorous and healthy, cluster and berry large dark violet color, delicious flavor.

MARGUERITE--Strong grower, resists mildew, endures Southwestern climate well, berry medium size, purple, quality good, arbor grape.

MUSCADINE-Should be planted with Scuppernongs to pollenize one to six or eight Scuppernong.

SCUPPERNONG-Cluster bears two to eight yellowish amber colored berries, thick skin, pulp tender for its class, prized for making Scuppernong wine.

FERN-Medium to large, dark purplish red, firm, agreeable flavor, a good drouth resister.

VERGENNES-Vine hardy, vigorous, healthy and productive, likely to mildew in South, eluster medium, berry medium, dull red

Prices For Grapes



\section{BLACKBERRIES AND DEWBERRIES}

Nothing is more sure, more abundant, healthier for use than Blackberries and Dewberries. They thrive throughout the widest range of conditions. Rich land and good culture are essential.

Blackberries-Specially recommended, about in order of ripening.

McDonald-A cross between blackberry and dewberry, very hardy and prolific and of fine quality. Ripens very early. One of the most valuable of all, requires other blackberries with it to pollenize.

Early Harvest-Very early, fruit medium, juicy, sweet, has a long fruiting season and carries well.

Dallas-A Texas berry, large black, firm and a strong grower. Very productive and reliable, good quality.

Queen-Native of black land of North Texas. The largest and most abundant early berry we have found, free from core, fine flavor, strong, upright grower after first year. Grows like Dewberry first year. Prices $\$ 3.50$ for $25, \$ 10.00$ per $100, \$ 85.00$ per 1000 .

Blackberries-Other varieties which we grow.

ROBISON-Originated in Texas, large delicious berries, very prolific, one of the most valuable for the Southwest.

HAUPT-An Evergreen blackberry, berries large and of good quality. Price $\$ 2.50$ for $25 ; \$ 8.50$ per $100 ; \$ 75.00$ per 1000 . 
HIMALAYA BERRY-An exceedingly strong grower, must have a trellis, very productive. $50 \mathrm{c}$ each, $\$ 5.00$ per dozen.

HOPKINS-Fine upright, abundant bearer, berry large, firm unexcelled in flavor. Price $\$ 2.50$ for $25 ; \$ \$ .50$ per $100 ; \$ 75.00$ per 1000 .

JORDAN-Large, upright, almost seedless, good bearer, fine quality.

Dewberries-Specially recommended.

Austin-Unquestionably the best dewberry for the Southwest. Fruit very large, acid, vigorous grower and heavy bearer.

OTHER DEWBERRIES-Also recommended.

ROGERS-A very early variety ripening in April, prolific.

Prices of Blackberries and Dewberries except as noted: $\$ 2.00$ for $25 ; \$ 7.50$ for $100 ; \$ 50.00$ for 1000 .

\section{QUINCES} flavor.

ANGERS-Fruit pear shaped, dull yellow, firm, dry but of good

CHAMPION-Very large, dull yellow, rich, aromatic flavor, tree vigorous and prolific-July to August.

MEECH-Large, bright orange yellow, beautiful and delightfully fragrant, fine for jellies and preserves. July to September.

ORANGE-Medium size rich orange yellow, most popular of the Quinces, August.

\section{Prices For Quinces}

\begin{tabular}{|c|c|c|c|}
\hline Large & $\begin{array}{l}\text { Each } \\
\$ 1.25\end{array}$ & $\begin{array}{l}\text { Dozen } \\
\$ 12.50\end{array}$ & $\begin{array}{c}100 \\
\$ 100.00\end{array}$ \\
\hline Medium & 1.00 & 10.00 & 80.00 \\
\hline Small . & (1) & 7.50 & 60.00 \\
\hline
\end{tabular}

\section{FIGS}

BROWN TURKEY-Adriatic, medium, violet-brown, sweet and good. Has the habit of bearing on the new shoots, even in the nursery rows and suited to North Texas as well as farther South.

BRUNSWICK-Large, irregular, light violet, excellent quality, very reliable and prolific. Not suited to coast section, but farther North, if frozen down in the winter, will put up new shoots and bear the same year.

MAGNOLIA-Large, pale violet of the Adriatic class, flavor excellent, bears on one year stems.

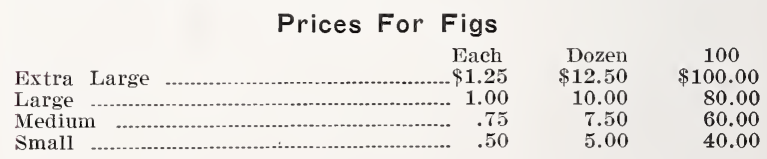

Currants and Gooseberries-50c each, $\$ 5.00$ per dozen.

These fruits are grown very little in the Southwest, but we handle sufficient of the best varieties to supply the small demand. Among the most popular Gooseberries are Downing and Houghton. 


\section{RASPBERRIES}

CARDINAL-Red, extra large and fine.

GREGG-Large, black. vigorous and productive.

KANSAS-One of the best, black, hardy and prolific.

MAMMOTH CLUSTER-Large. black, productive, hardy.

ST. REGIS- $\$ 5.00$ for $25 ; \$ 15.00$ for $100 ; \$ 100.00$ for 1000 . Red, the everbearing variets. lipening for four months, one crop in spring, and another in late summer and fall. Berries are large, juicy, sweet and of highest quality.

Prices of Raspberries except as noted: $\$ 3.00$ for 25 ; $\$ 8.50$ per 100 ; $\$ 75.00$ per 1000 .

\section{GARDEN ROOTS}

\begin{tabular}{|c|c|c|c|}
\hline & Each & Dozen & 100 \\
\hline GUS 2 years ol & & $\$ 1.00$ & $\$ 5.00$ \\
\hline N SAGE & .25 & 2.50 & 20.00 \\
\hline RADISH & & 1.00 & 5.00 \\
\hline 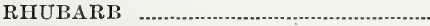 & .25 & 2.50 & 20.00 \\
\hline
\end{tabular}

\section{STRAWBERRIES}

The plants cannot be profitably grown for sale this far west, but we contract from the best growers every season enough of the best varieties to supply the demand and rour orders for strawberry plants will be properly taken care of, as we know the varieties that are best for the different sections.

\section{Prices For Strawberries}

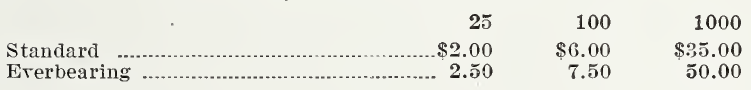




\section{ORNAMENTAL DEPARTMENT}

"Who plants a tree plants joy, plants peace. Plant! Life does the rest.

Heaven and earth help him who plants a tree, And his work its own reward shall be."

The love of the beautiful and artistic arrangement of home environments is the chief distinguishing characteristic of permanent civilization as against the rude makeshifts of barbarism.

"Teach your child of Eternity,

To love the things that last,

To think of the sturdy ancient tree

As part oi th'eternity that's past.

Teach him to use his own little hands,

A small bit of earth to move,

That he may see grow from his work in the sands

A temple to the God of Love.

Teach him to work with God each morn,

In nature's garden too,

To see what wonders God can perform,

From the little his hands may do."

Shade Trees-Suitable for most general use.

Elm, American White-The broad leaved, hardiest and most vigorous growing Elm and one of the best shade trees in America.

Hackberry-Thought by many to be the best shade tree for lawn or avenue, very healthy and vigorous.

Maple, Silver or Soft-A rapid growing beautiful tree, succeeds well in almost all soils.

Sycamore-An excellent avenue and lawn tree, endures well the dust and smoke of cities and thrives in more different kinds of soils and under more different climatic conditions than any other of the valuable shade trees.

\section{SHADE TREES}

To be used where they will give proper effect.

ASH WHITE-A valuable native tree.

BOX ELDER-A rapid growing native tree of spreading habit, BOIS D'ARC-A tree of rugged endurance, holding its glossy green foliage throughout the summer.

CATALPA SPECIOSA-Broad, deep green foliage, with fragrant trumpet flowers in spring, valuable for it's durable timber.

COTTONWOOD-One of the poplar family, does well in the plains country.

ELM, ENGLISH-Has rounded top and more compact than American, but of slower growth.

LOCUST BLACK-A good quick growing tree, used both for shades and for making posts and telephone poles.

MAIDENHAIR TREE OR GINKGO-Tall, sparsely branched slender.

MIMOSA-A small spreading tree bearing orange blossoms in spring and has beautiful foliage.

MULBERRY, RUSSIAN-Hardy and vigorous, used largely for wind break planting. 
POPLAR, BOLLE'S SILVER-A tall, beautiful columnar tree, resembling Lombardy poplar, but has beautiful silvery leaves.

POPLAR, CAROLINA-Rapid grower, no cottony blooms, specially adapted to plains country.

POPLAR, LOMBARDY-Wonderfully effective when properly placed, very tall, upright growing.

POPLAR, SILVER-Spreading, leaves green above and silvery on underside.

WALNUT-See nut trees for price.

\section{Prices For the Above Shade Trees}

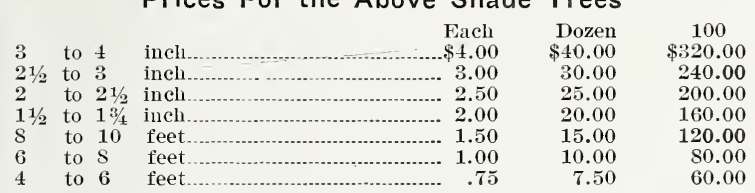

\section{List of Special Shade Trees and Their Prices}

Cypress, Deciduous-A beautiful pyramid shaped tree having the appearance of a cedar.

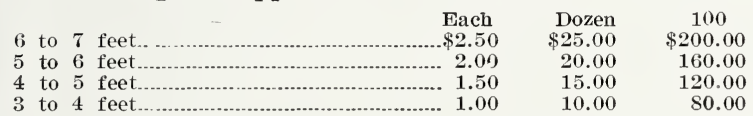

Mulberry, Paper White or Nonbearing-A very hardy quick growing spreading tree bearing no fruit, valuable for shade in arid sections.

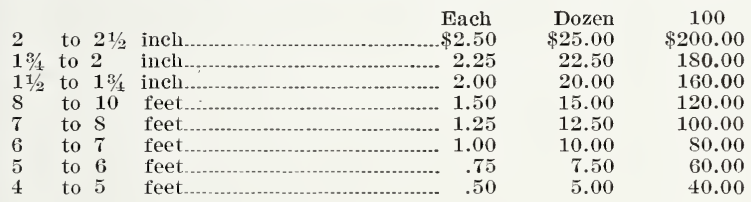

Texas Umbrella-Quick growing, perfect umbrella shape, making very dense shade.

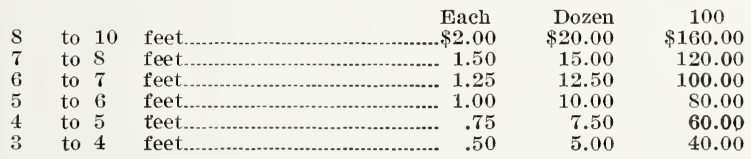

Willows, Weeping-Bark and leaves beautiful green, weeping habit.

\begin{tabular}{|c|c|c|c|c|}
\hline & & & Each & Dozen \\
\hline 8 & to 10 & feet. &.$\$ 2.50$ & $\$ 25.00$ \\
\hline 6 & to 8 & feet... & 1.50 & 15.00 \\
\hline 4 & to 6 & feet... & 1.00 & 10.00 \\
\hline 3 & to 4 & feet... & .75 & 7.50 \\
\hline
\end{tabular}

Empress Tree-Large heart shaped leaves, panicles of lilac colored flowers in spring, rapid grower.

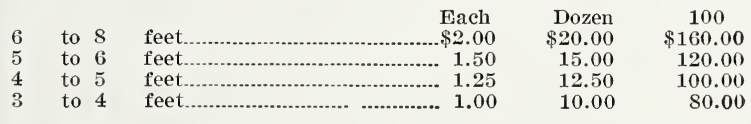

Japan Varnish or Chinese Parasol-Strong growing, green bark, tropical appearance, leaves broad deep and green, large panicles of yellow flowers.

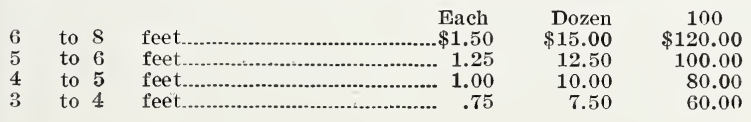


Live Oak-One of the most beautiful of the American Oaks, Evergreen.

\begin{tabular}{|c|c|c|c|}
\hline & & Each & Dozen \\
\hline 6 & to 7 & $\$ 5.00$ & $\$ 50.00$ \\
\hline 5 & to 6 & .... 3.50 & 35.00 \\
\hline 4 & to 5 & 2.50 & 25.00 \\
\hline 3 & to 4 & 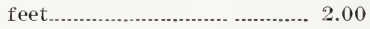 & 20.00 \\
\hline
\end{tabular}

Catalpa Bungeii-A beautiful umbrella shaped tree with broad leaves, making a unique ornament and a very dense shade.

\begin{tabular}{|c|c|c|c|c|c|}
\hline & & & Each & Dozen & 100 \\
\hline 2 & inch & diam. & $\$ 2.50$ & $\$ 25.00$ & $\$ 200.00$ \\
\hline $13 / 4$ & inch & diam.. & .2 .00 & 20.00 & 160.00 \\
\hline $11 / 2$ & inch & diam.. & 1.50 & 15.00 & 120.00 \\
\hline $11 / 4$ & inch & diam. & 1.25 & 12.50 & 100.00 \\
\hline 1 & inch & diam. & 1.00 & 10.00 & 80.00 \\
\hline
\end{tabular}

Willow Oak-Conical, round headed, leaves glossy green.

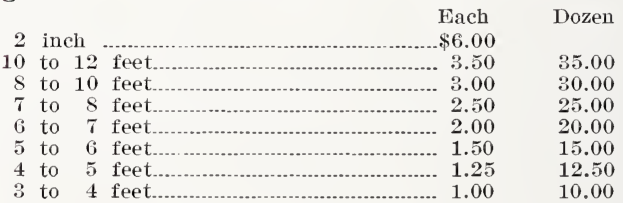

Shade Tree Seedlings-We grow Catalpa Speciosa, Black Locust, Soft Maple, Russian Mulberry and other seedlings for forest or wind break.

\begin{tabular}{|c|c|c|}
\hline 1000 lots & $\begin{array}{c}5 \text { to } 10 \mathrm{M} \\
\text { lots }\end{array}$ & $\begin{array}{l}10 \text { M lots } \\
\text { or more }\end{array}$ \\
\hline Black Locust & $\$ 8.50$ & $\$ 6.00$ \\
\hline Bois d'Are. & 8.50 & 6.00 \\
\hline Catalpa Speciosa ... & 8.50 & 6.00 \\
\hline Maple, Box Elder and Ash................ 12.00 & 10.00 & 8.00 \\
\hline Sycamore and Umbrella China............ 12.00 & 10.00 & 8.00 \\
\hline Russian Mulberry ................................. 100 & 8.50 & 6.00 \\
\hline
\end{tabular}

\section{SHRUBS}

Specially adapted to Southwest.

Almond, Flowering-An old favorite; blooms early in the spring before the leaves appear; very attractive in borders and foundation plantings; in two colors; either pink or white.

Althea, or Rose of Sharon-An upright grower, flowers of different colors; somewhat resembling the hollyhock; very hardy; withstands drouth; blooms from July till frost. We offer the following colors in both single and double flowers:

Pure. White, Pink, Lavender, Purple, Red, Variegated (Pink and White).

Althea-Besides those mentioned above, we have a number which have been bred up to the highest standard of blcoming qualities, and offer the ones mentioned below.

Admiral Dewey-Double; pure white, medium. Amplissima-Double, deep purplish pink, carmine center, tall.

Carnea Plena-Semi-double; flesh, medium.

Granville-Semi-double; flesh, crimson, center, medium.

Lady Stanley-Double, white, shaded rose crimson center, medium.

Meehanii-Single; lavender, variegated leaves; dwarf.

Pompon Rouge-Double; red; medium.

Totus Albus-Single; pure white; dwarf. 
Bird of Paradise-Lea - long and narrow, similar to Indigo; flowers orange with brilliant red stamens protruding 3 to 5 inches. Good for dry sections.

Bush Honeysuckles-These vigorous, tall-growing shrubs are invaluable for planting in masses or in borders; exceptionally well adapted to the Southwest.

White Tartarian Bush Honeysuckle-Large white flowers.

Pink Tartarian Bush Honeysuckle-Rose colored flowers.

Butterfly Bush-Blooms continuously throughout the summer; flowers resemble the lilac.

Chaste Tree-A very rapid grower, splendid for use in backgrounds and to hide high fences; foliage grayish green, resembling sage to a degree; flowers in spikes of pale blue.

Crape Myrtle-The most gorgeous of all blooming shrubs for the Southwest. Blooms throughout the entire summer; withstands drouth wonderfully. Crape Myrtle is very effective for hedges, and is at its best when pruned every winter and not allowed to grow in tree form. We can furnish pink, light pink, red, purple and white.

Elder Fern-Leaved-A European variety of the old fashioned Elderberry, its finely cut foliage and white flowers rendering it very attractive.

Elder, Golden-Golden leaves; black berries; very attractive, especially in connection with the deep green of other shrubs, must be planted in sunlight to secure the best color effects.

Golden Bell-A very graceful shrub, with slender, arching branches; yellow flowers in great profusion in early spring.

Indian Currant-Rather dwarf-growing native shrub white flowers in spring followed by profusion of red berries in fall; very hardy and drouth-enduring.

Japan Quince-One of the most popular shrubs. Usually has bright red flowers, but the color varies from bright red to almost white. The plant has a rather twisted form of growth giving a decided Japanese effect. Blooms in early spring.

Jasmine, Yellow-Planted in a warm, sunny corner, this low-growing, spreading shrub will give a wealth of bright yellow flowers in February. It can also be trained on a trellis and grown as a vine.

Lilac-The old-fashioned Lilacs, loved by the gcnerations that are gone. We offer the purple and white of these old acquaintances as well as the following:

Lilac, Persian-A graceful shrub with finely cut foliage and delicate lavender blossoms. Blooms are not so large as the Common Purple, but it is a more graceful shrub.

\section{Named Varieties of Lilacs}

There is no comparison between these named varieties and the Common Lilacs. Their richness of coloring is wonderful, as well as the size of each blossom 
and of the panicles. Once seen, they cannot be resisted. We know they are well adapted to the Southwest, for we have had them blooming for several seasons in a field unprotected from the Western sun.

Alphonse Lavalle-Double flowers, bluish lilac in color.

Belle de Nancy-Double flowers, pink with white center.

Frau Bertha Dammann-Single flowers, white.

Ludwig Spaeth-Single flowers, dark purple.

Mme. Abel Chatenay-Double flowers, white.

Marie LeGraye-Single flowers, white.

Mock Orange, or Syringa-The old-fashioned "Sweet Syringa," with fragrant white flowers. The long branches covered with a profusion of starry white flowers are exceedingly beautiful; blooms in early spring, suitable for massing with other shrubs or planted as specimens.

Peach, Flowering-A very pretty specimen tree, or for use in the shrubbery border. Similar to the ordinary Peach tree in appearance, except that the blossoms are double, resembling small roses. The blooming season is short, but this tree is worthy of being planted for its extreme beauty during even so short a time. We offer white, pink and red.

Plum, Purple-Leaved-An upright-growing tree; foliage of a decided purple hue.

Privet, Amoor River-The best of all, as it is almost an evergreen retaining its leaves all winter except under unusual weather conditions. Is also used for hedges, but for this purpose we offer a different grade of plants. See under "Hedge Plants."

Privet, Chinese-A very handsome shrub, with spreading, slender branches; white flowers followed by clusters of black berries; semi-evergreen.

Red Bud, or Judas Tree-One of the most showy of the early, spring flowering, small trees or shrubs. The branches are completely covered with the rosepink flowers before the leaves appear. Very effective when planted with a background of evergreens.

Salvia, Hardy-A native of Texas and Mexico. Dwarf grower; blooms throughout the summer; flowers a rich rosy red.

Snowberry-Of rather dwarfish growth; very graceful branches; the large white berries are very attractive.

\section{SPIREA}

Snow Garland-Low growing; finely cut foliage; plant entirely covered with tiny white flowers in early spring.

Bridal Bower-The grandest of all the Spireas and one of the most magnificent shrubs. The branches are exceedingly graceful, making it a most attractive shrub throughout the entire year, and, when in bloom, with each slender branch carrying its load of white blossoms, it is unsurpassed.

Tamarisk, African-Tall, upright growing, with soft, feathery foliage and panicles of pinkish lavender flowers. 
Tamarisk Japonica-Splendid for use in the background of a shrubbery border; tall and slender; foliage bluish green and flowers pink.

Willow, Flowering-A tall-growing shrub; leaves resembling the Willows; blooms throughout the summer; flowers trumpet-shaped, tube throat lilac with two yellow stripes inside. We also have the pure white variety.

\section{Other Varieties of Shrubs That We Grow}

ACACIA ROSEA-The flowers are a soft rose color, in panicles like the Wistaria; blooms in early summer for a period of about four weeks.

BARBERRY, COMMON-Yellow flowers in early spring, followed by red fruits in the fall. Branches arching.

BARBERRY, JAPANESE-Dense, low-growing shrub, branches spreading.

BARBERRY, PURPLE-LEAVED-Foliage dark, redish purple.

BASTARD INDIGO-Flowers in long panicles, dark purple. pink.

CRAB, BECHTEL'S FLOWERING-Flowers large and double,

CRAB, DOUBLE-FLOWERING-Rose-colored blossoms.

CALYCANTHUS-Sweet scented flowers.

DEUTZIA-A very showy shrub in early spring.

CANDIDISSIMA-Double white flowers.

CRENATA-Single white flowers.

GRACILLIS-Pretty, small white flowers. pink

PRIDF OF ROCHESTER-Double flowers, white tinged with DOGWOOD-White flowers.

DOGWOOD-Red bark; white flowers.

FRINGE, PURPLE, or SMOKE TREE-Masses of grayish purple blooms.

FRINGE, WHITE-Dark green foliage and elouts of snowy blossoms.

GOLDEN BELL, DROOPING-Yellow flowers in early spring.

GOLDEN BELL-Green twigged, flowers greenish yellow.

HARDY HYDRANGEA, LAWN-Pure white flowers in July.

HARDY HYDRANGEA, HILLS OF SNOW-Large clusters of white flowers.

HARDY ORANGE-(See Hedge Plants) Treen bark, thick rugged thorns; white, fragrant blossoms in spring.

INDIGO SHRUB-Flower a beautiful shade of rose.

JAPANESE OLEASTER-Grows about 6 feet tall.

KERRIA, WHITE-White flowers in May, followed by jetblack seeds.

MISSOURI CURRANT-Yellow flower in spring.

MOCK ORANGE-Flowers are large and not sweet scented.

NEW JERSEY TEA-Flowers small but in large, showy pani.cles

PEARL BUSH-Large white blossoms in May.

PRIVET, CALIFORNIA-Used chiefly as a hedlge plant.

PRIVET, NEPALENSE-Fxtremely graceful evergreen shrub.

PRIVET, REGAL'S-White flowers followed by black berries.

RUSSIAN OLIVE--Silvery foliage and yellow berries.

SNOWBALL-Showy flowers in large white "balls" in April.

\section{Spirea}

EVERBLOOMING COMMON-Blossoms a deep pink.

BILLARDII-Flowers in panicles of delicate pink. vals.

FORTUNE'S WHITE-Flowers white and blooming at inter-

BRIDAL WREATH-Pure white flowers in early spring.

FONTENAYSII-Flowers iu white panicles.

DOUGLASII-Deep pink flowers in June and July.

WEIGELA, CARMINE-Flowers deep carmine.

WEIGELA, PINK-Flowers rich pink. 


\section{Prices For Shrubs, Except as Noted}

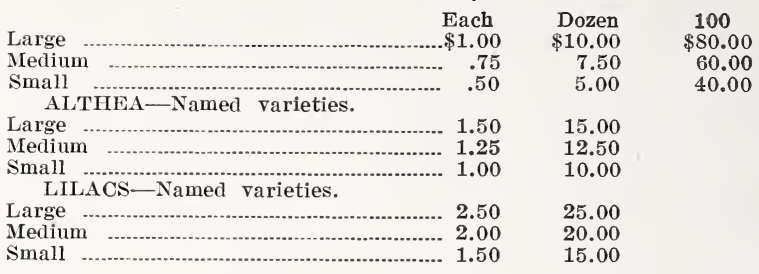

\section{VINES}

Specially adapted to the Southwest.

Clematis, Japanese-A rapid, vigorous grower; foliage dainty and pleasing; flowers small but in great profusion; the best Clematis for the Southwest.

Honeysuckle, Chinese-Leaves very dark green; flowers white and yellow, an everblooming sweetscented variety.

Honeysuckle, Hall's Japan-A late-flowering variety, holding its foliage all through the winter.

Ivy, Boston-The best known of all the vines. Clings to brick and stone, clinging very closely to the surface. Foliage a deep green all summer, changing to rich crimson in the fail.

Kudzu, Japanese-A very rapid grower with immense leaves; makes a thick shade; especially desirable for covering porches where the home faces the west. We advise cutting back each winter, as it grows so rapidly, but if not cut back, leaves will come on the old wood. A splendid vine where quick shade is wanted.

Trumpet Vine-An early bloomer, bearing large flowers of brilliant orange-red.

Trumpet Vine, Scarlet-A rapid growing vine with rich green foliage and flowers of a rich crimson.

Virginia Creeper-A native American vine; extremely rapid grower, leaves are deeply cut and turn to a beautiful shade of crimson in the fall.

Wistaria, Chinese-The wonderfully beautiful flower of Japan. It grows rapidly, being particularly well adapted for covering pergolas and portecocheres. In April when in bloom immense clusters of lavender flowers are beautiful beyond description.

\section{Other Varieties of Vines That We Grow}

BITTERSWEET-Flowers orange-yellow in June with crimson fruit in the fall.

BITTERSWEET, JAPANESE-Brilliant-colored fruit in th 2 fall. CLEMATIS, LARGE WHITE-Large white flowers.

CLEMATIS, PURPLE-Large, deep purple blossoms.

CLEMATIS, RED-Large red flowers.

CLEMATIS, STAR OF INDIA-Large purple flowers, barred with red.

HONEYSUCKLE, JAPANESE-Dark green foliage; fragrant yellow flowers.

HONEYSUCKLE, SCARLET TRUMPET-Semi-evergreen; scarlet flowers.

IVY, ENGLISH-A beautiful dark green evergreen vine.

MATRIMONY VINE-Grayish green foliage; violet flowers in spring, followed by scarlet fruit.

MYRTLE-A spreading evergreen. 
PIPE VINE, or DUTCHMAN'S PIPE-Large thick, shining leaves of a light green color; flowers purplish.

QUEEN'S WREATH-Leaves and flowers heart-shaped; blossoms pink.

WISTARIA, WHITE--Flowers white.

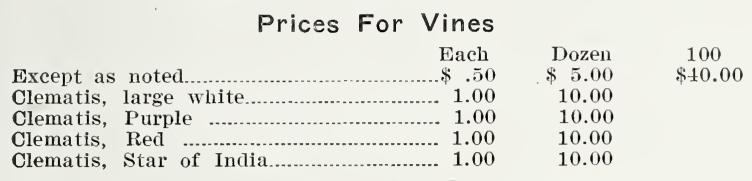

\section{HEDGE PLANTS}

Specially adapted to the Southwest.

Evergreen Euonymus-Makes a very attractive evergreen hedge; leaves broad with glossy surface. 18 to 24 inch $\$ 7.50$ per doz.; $\$ 60.00$ per $100 ; 12$ to 18 inch $\$ 5.00$ per doz.; $\$ 40.00$ per $100 ; 8$ to 12 inch $\$ 3.00$ per doz.; $\$ 24.00$ per $100 ; 6$ to 8 inch $\$ 2.00$ per doz.; $\$ 16.00$ per 100 .

Hardy Orange-A very ornamential hedge plant and especially desirable because of the fact that it answers the purpose of a ferice and stock will not break through it. Both foliage and twigs are green, white flowers in spring followed by small orange like fruit. One of the best hedges, 2 to 3 feet $\$ 2.50$ per doz.; $\$ 20.00$ per $100 ; \$ 160.00$ per $1000 ; 18$ to 24 inch $\$ 2.00$ per doz.; $\$ 16.00$ per $100 ; \$ 120.00$ per $1000 ; 12$ to 18 inch $\$ 1.50$ per doz.; $\$ 12.00$ per $100 ; \$ 90.00$ per $1000 ; 6$ to 12 inch $\$ 1.00$ per doz.; $\$ 8.00$ per $100 ; \$ 60.00$ per 1000 .

Privet, Amoor River-The finest hedge plant for the Southwest; grows rapidly; withstands drouth; holds its foliage well, frequently during the entire winter. Can be kept sheared to any height and in any shape desired. 2 to 3 feet $\$ 3.00$ per doz.; $\$ 24.00$ per $100 ; \$ 180.00$ per $1000 ; 18$ to 24 inch $\$ 2.50$ per doz.; $\$ 20.00$ per $100 ; \$ 150.00$ per $1000 ; 12$ to 18 inch $\$ 2.00$ per doz.; $\$ 16.00$ per $100 ; \$ 120.00$ per 1000 .

Other Varieties of Hedge Plants That We Grow

BARBERRY, JAPANESE--Fully described under "Shrubs." 12 to 18 inch $\$ 2.50$ per doz.; $\$ 20.00$ per 100 .

BOX, DWARF-This is the old fashioned Box, 6 to 8 inch $\$ 4.50$ per doz.; $\$ 36.00$ per $100 ; 4$ to 6 inch $\$ 3.00$ per doz.; $\$ 24.00$ per 100 .

BOX, TREE-The bush-shaped Box. 12 to 18 inch $\$ 7.50$ per doz.; $\$ 60.00$ per $100 ; \$$ to 12 inch $\$ 5.00$ per doz.; $\$ 40.00$ per 100 .

PRIVET, CALIFORNIA-A very rapid growing hedge plant, giving beautiful effects; does not hold its foliage so late as Amoor River Privet. 2 to 3 feet $\$ 1.50$ per doz.; $\$ 12.00$ per $100 ; \$ 75.00$ per $1000 ; 1 \mathrm{~S}$ to 24 inch $\$ 1.25$ per doz.; $\$ 10.00$ per $100 ; \$ 60.00$ per $1000 ; 12$ to 18 inch $\$ 1.00$ per doz.; $\$ 8.00$ per $100 ; \$ 50.00$ per 1000 .

\section{EVERGREENS}

Specially adapted to the Southwest.

\section{CONIFEROUS EVERGREENS}

Arborvitae, Chinese-Tall growing and of spreading habit, foliage coarse and dark green.

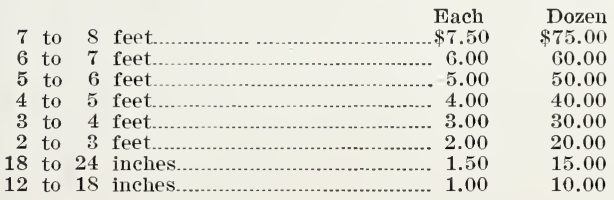


Arborvitae, Golden-Very compact growth, foliage golden.

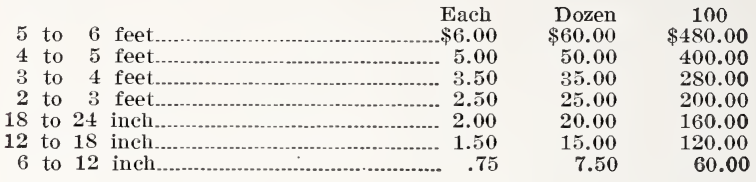

Arborvitae, Compact-A more compact form of the Chinese. Price same as Arborvitae Golden.

Arborvitae, Dwarf-A low-growing variety whole foliage has a l'ecided golden tint.

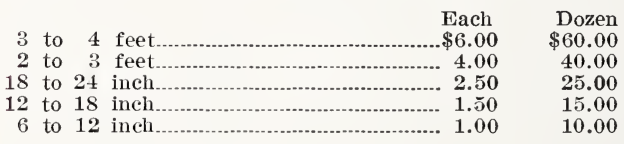

Arborvitae, Pyramidal-Forms a tall narrow pyramid, foliage dark green. Price same as Arborvitae, Golden.

Cedar, Red-The well known cedar. Really gives the best effect when allowed to branch from the ground, though it is frequently trimmed to about 10 feet above the ground. Foliage a dark green; seeds in silvery blue pods.

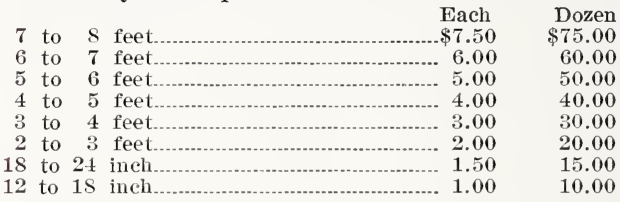

Cedar, Mt. Altas-Similar to C. Deodara.

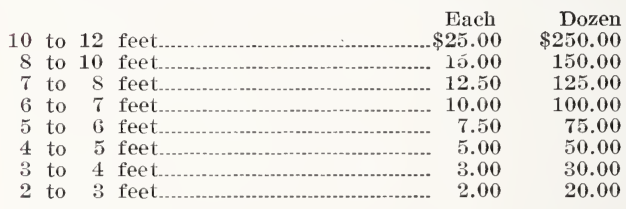

Cedar, Himalayan-(C. Deodara) Finest of the coniferous evergreens for the South; resembles the blue spruce in color of foliage; pyramical in growth, attaining a height of 50 to 100 feet. No group of evergreens in the Southwest is complete without a specimen of this beautiful cedar. Price same as the Cedar, Mit. Altas.

\section{Other Varieties of Coniferous Evergreens That We Grow}

ARBORVITAE, ROSEDALE-Foliage pale green, feathery. Price same as the Arborvitae Golden.

CYPRESS, LAWSON'S-A beautiful cone-shaped evergreen. Price same as Arborvitae, Golden.

JUNIPER, IRISH-Slender, tall growing; foliage a bluish green. Price same as Arborvitae, Golden.

PINE, AUSTRIAN-Needles very dark green. Price same as Arborvitae Golden.

PINE, SCOTCH-Needles a yellowish green. Price same as Arborvitae Golden.

YEW, ENGLISH-A dark green evergreen.

$\begin{array}{rrrrr}2 & \text { to } 3 \text { feet } & \text { Each } & \text { Dozen } \\ 18 \text { to } 24 \text { inch } & \$ 2.50 & \$ 25 .(1) \\ 12 \text { to } 18 \text { inch } & 15.0 .\end{array}$




\section{BROAD LEAVED EVERGREENS}

Abelia Grandiflora-Leaves a glossy dark green, rather small; flowers small, white tinted pink; blooms profusely from June until frost.



Euonymus-Broad, deep green, glossy leaves; erect growing.

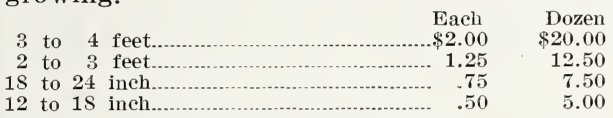

Jasmine, Italian Yellow-Small, deep green leaves; bright yellow flowers.

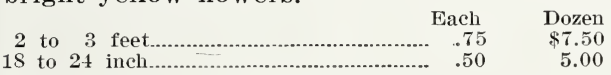

Magnolia-(Grandiflora) Perhaps the finest Magnolia. Reaches height of 80 feet. It's dark, glossy evergreen foliage and immense white fragrant flowers followed by bright red seed pods, make it one of the finest ornamental trees we have.

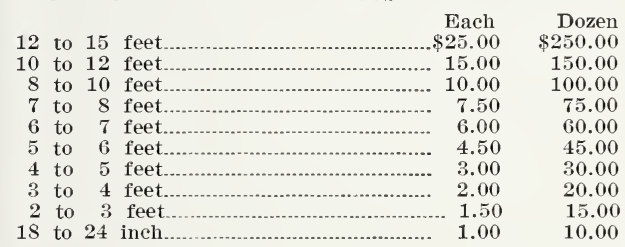

Mahonia-Leaves resemble those of the Holly; large bunches of small flowers in spring, followed by showy clusters of blue-black berries; low growing and spreading.

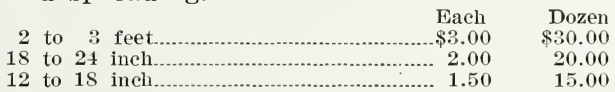

Photinia-Slow growing, bushy; foliage dark green, leaves resembling the leaf of a pear; clusters of small white flowers.

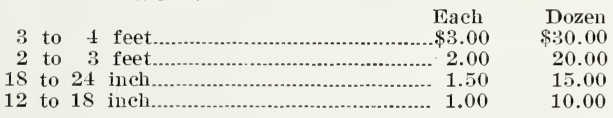

Wild Peach-A beautiful evergreen tree; foliagt dark green and glossy, leaves small; attains a height of from 20 to 40 feet. May be pruned or sheared in any desired shape. Prices same as for Magnolia Grandiflora.

\section{Other Varieties of Broad Leaved Evergreens That We Grow}

CAPE JASMINE-Foliage thick, dark green in color, large; white flowers with extremely sweet odor; early spring.

\begin{tabular}{|c|c|c|c|}
\hline 3 to & feet.. & $\begin{array}{l}\text { Each } \\
\$ 2.00\end{array}$ & $\begin{array}{l}\text { Dozen } \\
\$ 20.00\end{array}$ \\
\hline 2 to 3 & feet.. & 1.25 & 12.50 \\
\hline 18 to 24 & inch & .75 & 7.50 \\
\hline 2 to 18 & inch & .50 & 5.00 \\
\hline
\end{tabular}




\section{GRASSES}

That are adapted to the Southwest.

BARRED EULALIA-The long leaves are marked across with bars of yellow.

GIANT REED-Very tall growing, sometimes 12 to 15 feet high. Especially effective along the banks of streams or lakes and also used in shrubbery plantings and to screen unsightly objects.

GIANT REED, VARIEGATED-Similar to above, except that the leaves show creamy white stripes.

PAMPAS GRASS-Leaves 6 to 8 feet long, plumes 8 to 10 feet high. Excellent for use in the center of canna beds or other perennials.

LYME GRASS-Hardy perennial; grows 3 to 5 feet high; excellent for edging shrubbery beds.

\begin{tabular}{|c|c|c|c|}
\hline & Prices For Gi & rasses & \\
\hline Fxtra Large & & $\begin{array}{l}\text { Each } \\
. . \$ 1.00\end{array}$ & $\begin{array}{r}\text { Dozen } \\
\$ 10.00\end{array}$ \\
\hline arge ......... & & $\ldots .75$ & 7.50 \\
\hline edium & & .50 & 5.00 \\
\hline
\end{tabular}

\section{BULBS AND PERENNIALS}

Specially recommended ior the Southwest.

Bouncing Bet-Low growing, flower slightly tinged pink, double and fragrant, from July till frost. Can be grown with great success in any soil or situation. $25 \mathrm{c}$ each; $\$ 2.50$ per doz.; $\$ 20.00$ per 100 .

Chrysanthemum, Hardy-Small flowers in clusters. We have red, yellow and white. They make a gorgeous show in late summer and fall. They are specially valuable for prolonging the season of bloom in the garden. 35c each; $\$ 3.50$ per doz.; $\$ 28.00$ per 100 .

\section{CANNAS}

Canna, Austria-Green leaves; lemon-yellow flowers; $10 \mathrm{c}$ each: $\$ 1.00 \mathrm{p} \in \mathrm{r}$ doz.; $\$ 8.00$ per 100 .

Alphonse Bouvier-Green leaves; profuse bloomer, $10 \mathrm{c}$ each; $\$ 1.00$ per doz.; $\$ 8.00$ per 100 .

Buttercup-Green leaves; profuse bloomer, yellow, 20c each; $\$ 2.00$ per doz.; $\$ 16.00$ per 100 .

Egandale-Bronze leaves; red flowers, $10 \mathrm{c}$ each; $\$ 1.00$ per doz.; $\$ 8.00$ per 100 .

Hungaria-Green leaves; flowers the same beautiful shade of pink as the well known Paul Neyron rose, $25 \mathrm{c}$ each; $\$ 2.50$ per doz.; $\$ 20.00$ per 100 .

J. D. Eisle-Green leaves; fiery orange red flowers, $15 \mathrm{c}$ each; $\$ 1.50$ per doz.; $\$ 12.00$ per 100 .

Koros-Bronze leaves; flowers orange scarlet, $20 \mathrm{c}$ each; $\$ 2.00$ per doz.; $\$ 16.00$ per 100 .

Louisiana-Green leaves; flowers glowing scarlet, $12 \frac{1}{2}$ c each; $\$ 1.25$ per doz.; $\$ 10.00$ per 100 .

King Humbert-Bronze leaves; flowers orange scarlet, $12 \frac{1}{2} \mathrm{c}$ each; $\$ 1.25$ per doz.; $\$ 10.00$ per 100 .

Madame Crozy-Green leaves; flowers orange, mottled scarlet and edged bright golden yellow, 10c each; $\$ 1.00$ per doz.; $\$ 8.00$ per 100 .

Shenandoah-Bronze leaves; flowers salmonpink; $12 \frac{1}{2}$ c each; $\$ 1.25$ per doz.; $\$ 10.00$ per 100 .

Crinum Fimbriatulum-Milk and Wine Lily, grows well in almost any soil; flowers in umbels, striped white and carmine. $35 \mathrm{c}$ each; $\$ 3.50$ per doz; $\$ 25.00$ per 100 . 
Daffodil-Leaves very slender; flower bright yellow, blooms in early spring. Bulbs must be planted in the fall. $15 \mathrm{c}$ each; $\$ 1.50$ per doz.; $\$ 12.00$ per 100 .

Day Lily, or Homestead Lily-Beautiful orange colored flowers on tall stems in June and July. Clumps subject to dividing into 6 to 12 plants. $25 \mathrm{c}$ each; $\$ 2.50$ per doz.; $\$ 20.00$ per 100 .

Day Lily or Yellow Day Lily-Fine large orangeyellow flowers in June and July, dwarf growing, free blooming. Clumps subject to dividing into 4 to 10 plants, 35c each; $\$ 3.50$ per doz.; $\$ 25.00$ per 100 .

Day Lily, or Lemon Lily-Latest blooming of the Lemon Lillies. Flowers bright lemon color in June and July, on stems about 3 feet tall. Clumps subject to dividing into 4 to 10 plants. $35 \mathrm{c}$ each, $\$ 3.50$ per doz.; $\$ 25.00$ per 100 .

Gladiolus-Spikes of very showy flowers in assorted colors. Splendid for cut flowers. By planting the bulbs at different times a succession of blooms may be secured. After flowering, bulbs should be stored in winter. $15 \mathrm{c}$ each; $\$ 1.50$ per doz.; $\$ 12.00$ per 100.

Golden Glow-Bright yellow, double flowers in late summer, continuing till frost. 2 to 7 feet. $35 \mathrm{c}$ each; $\$ 3.50$ per doz.; $\$ 28.00$ per 100 .

Goldenrod-The golden beauty of the autumn. An excellent variation of this almost national flower. 25 c each; $\$ 2.50$ per doz.; $\$ 20.00$ per 100 .

Hyacinth, Dutch-Thick green leaves with racemes of bell-like blossoms in early spring. Assorted colors; must be planted in the fall, 5 to 18 inches. $15 \mathrm{c}$ each; $\$ 1.50$ per doz.; $\$ 12.00$ per 100 .

Iris, German-Leaves in pale green spikes; flowers stand well above the foliage; one of the earliest perennials to come into flower. The variety of coloring is almost endless, comprising every shade of purple, bronze, blue, gold and white. Clumps subject to dividing into 6 to 12 plants $25 \mathrm{c}$ each; $\$ 2.50$ per doz.; $\$ 20.00$ per 100 .

Larkspur-Good plant for borders; 35c each; $\$ 3.50$ per doz.; $\$ 28.00$ per 100 .

Lavender Cotton-Small silvery gray leaves and small yellow flowers in summer. 25c each; $\$ 2.50$ per doz.; $\$ 20.00$ per 100 .

Lespedeza-Slender willowy branches with rather dense clover like foliage; purplish red pea-shaped flowers in profusion in summer and autumn. $75 \mathrm{c}$ each; $\$ 7.50$ per doz.; $\$ 60.00$ per 100 .

Narcissus-Old-fashioned favorite; single white waxen flowers in early spring. Plant in fall only. $35 \mathrm{c}$ each; $\$ 3.50$ per doz.; $\$ 28.00$ per 100 .

Perennial Pea-Flowers as large and varied as the sweet pea but having no odor. Specially good for covering wild, rough places. $25 \mathrm{c}$ each; $\$ 2.50$ per doz.; $\$ 20.00$ per 100 .

Plumbago Larpentae-Low growing, very hardy and produces a profusion of deep blue flowers from June until frost. Very fine for borders. 50c each; $\$ 5.00$ per doz.; $\$ 40.00$ per 100 .

Shasta Daisy-Large white flowers, yellow center; rich soil and reasonable moisture required for best results. 35c each; $\$ 3.50$ per dozen; $\$ 28.00$ per 100 .

Stokes' Aster-Hardy, well known plant; lavender blossoms, 2 to 3 feet. $35 \mathrm{c}$ each; $\$ 3.50$ per doz.; $\$ 28.00$ per 100 . 
Stonecrop-Low growing; showy clusters of light pink flowers in September; leaves pea-green, waxy, 35 c each; $\$ 3.50$ per doz.; $\$ 28.00$ per 100 .

Tickseed-Clear yellow flowers, through June to August. 25c each; $\$ 2.50$ per doz.; $\$ 20.00$ per 100 .

Tuberose, Mexican-Its great wax like flowers from July till frost make this one of the most desirable of the bulbs, especially as they will bloom in rather dry soil, but flourish and produce heavily in rich, moist soil. $10 \mathrm{c}$ each; 1.00 per doz.; $\$ 7.50$ per 100 .

Tulips-Both double and single, assorted colors. Plant in fall only. $15 \mathrm{c}$ each; $\$ 1.50$ per doz.; $\$ 10.00$ per 100 .

\section{Other Varieties of Bulbs and Perennials That We Grow}

AMARYLLIS BELLADONNA-Pink, lily-like flowers. 50c each; $\$ 5.00$ per doz. ; $\$ 40.00$ per 100 .

AMARYLLIS EQUESTRIS-Flowers pure orange, lily shaped. 50 c each; $\$ 5.00$ per doz. ; $\$ 40.00$ per 100 .

AMARYLLIS VITTATA-Petals thick, crisp, and velvety; open lily like flowers, rich red and white; $50 \mathrm{c}$ each; $\$ 5.00$ per doz. $\$ 40.00$ per 100 .

BLAZING STAR-Purple spike-like flowers on wand-like racemes. 35c each; $\$ 3.50$ per doz. ; $\$ 28.00$ per 100 .

BOLTONIA, WHITE-White flowers resembling daisies. 35c each; $\$ 3.50$ per doz.; $\$ 28.00$ per 100 .

BOLTONIA, LILAC-Flowers lilac colored, $35 \mathrm{c}$ each; $\$ 3.50$ per doz.; $\$ 2 \$ .00$ per 100 .

CHINESE BELLFLOWER-Deep blue, 35c each; $\$ 3.50$ per doz. ; $\$ 28.00$ per 100 .

CHINESE BELLFLOWER-Same as above except flowers white, 35 c each; $\$ 3.50$ per doz.; $\$ 28.00$ per 100 .

CRINUM AUGUSTUM-Pinkish mauve, light striped, sweet scented flowers, $\$ 1.00$ each; $\$ 10.00$ per doz. ; $\$ 80.00$ per 100 .

CRINUM KIRKII-Flowers large white with redish purple stripe on outside of each petal, 35c each; $\$ 3.50$ per doz. $; \$ 25.00$ per 100.

CRINUM KUNTHIANUM-White tinged with rose-red, 35c each; $\$ 3.50$ per doz. ; $\$ 25.00$ per 100 .

EUPATORIUM-Purple flowers in clusters, $35 \mathrm{c}$ each ; $\$ 3.50$ per doz. ; $\$ 28.00$ per 100 .

FALSE DRAGON HEAD-White flowers in July and September, $35 \mathrm{c}$ each ; $\$ 3.50$ per doz. ; $\$ 28.00$ per 100 .

GAILLARDIA-Flowers deep yellow, 35c each; $\$ 3.50$ per doz.; $\$ 28.00$ per 100 .

GAS PLANT-Old garden favorite, two colors, white and red, $35 \mathrm{c}$ each ; $\$ 3.50$ per doz. ; $\$ 28.00$ per 100 .

HOLLYHOCK-Long wand-like racemes of flowers, $35 \mathrm{c}$ each ; $\$ 3.50$ per doz.; $\$ 28.00$ per 100 .

IRIS, JAPANESE-Leaves and stems of flowers more slender than the German, 50c each; $\$ 5.00$ per doz. ; $\$ 35.00$ per 100 .

IRIS, SNOW QUEEN-Same white flowers but not so tall growing as the Japanese, 50c each; $\$ 5.00$ per doz. ; $\$ 35.00$ per 100 .

MARGUERITE DAISY-Single white flowers, 35c each; $\$ 3.50$ per doz. ; $\$ 28.00$ per 100 .

ORANGE SUNFLOWER-F'lowers 2 to 3 inches in diameter, $35 \mathrm{c}$ each; $\$ 3.50$ per doz.; $\$ 28.00$ per 100 .

PENTSTEMON-Large purplish white flowers, 35c each; $\$ 3.50$ per doz. ; $\$ 28.00$ per 100 .

PEONY-Assorted colors of this old fashioned flower, 50c each ; $\$ 5.00$ per doz.; $\$ 40.00$ per 100 .

PERENNIAL PHLOX-This old-fashioned flower should also be planted where it will be protected from the afternoon sun and for best results should have the flower-stems cut off short as soon as the first flower begins to fade. $35 \mathrm{c}$ each; $\$ 3.50$ per doz. ; $\$ 28.00$ per 100 . 
RED HOT POKER-Blazing red flowers, in August. 35e each; $\$ 3.50$ per doz.; $\$ 25.00$ per 100 .

SEA LAVENDER-Blue flowers in mid summer. 35e each; $\$ 3.50$ per doz.; $\$ 28.00$ per 100 .

UPRIGHT VIRGIN'S BOWER-Flowers white, scented, June to September. 35e each; $\$ 3.50$ per doz. ; $\$ 28.00$ per 100 .

VIOLETS-The well-known sweet violets. Single plants, $10 \mathrm{c}$ each; $\$ 1.00$ per doz. $; \$ 6.00$ per 100 . Clumps $25 \mathrm{e}$ each; $\$ 2.50$ per doz.; $\$ 20.00$ per 100 .

\section{ROSES}

Specially adapted to the Southwest.

American Beauty-The Queen of Roses. Deep pink, extremely fragrant, perfection for cut-flowers, stems with foliage close up to flower, very few thorns.

Antoine Rivoire-Creamy white, delicately tinged with salmon-pink.

Bessie Brown-White tinged pink, center deep pink.

Bon Silene-Deep pink.

Bridesmaid-Clear shiny pink.

Climbing Kaiserin Augusta Victoria-Same as Mrs. Robert Peary.

Dorothy Perkins-The best climbing Rose for the Southwest. Shell-pink in large clusters; sweet scent$\epsilon d$.

Etoile De France-Clear red.

Frau Kari Druschki-White American Beauty.

Gruss an Teplitz-Rich velvety crimson.

Helen Gould-Rosy Pink.

Kaiserin Augusta Victoria-Ivory-white, double, probably the very best white rose grown.

La France-Silvery rose.

Maman Cochet-Rich rosy pink.

Meteor-Intense velvety crimson.

Mrs. Robert Peary-(Climbing Kaiserin Augusta Victoria) Ivory white, identical with Kaiserin Augusta Victoria, except as to its climbing habit.

Paul Neyron-Probably the largest blossoms of any Rose, bright, shining, clear beautiful pink, very double, full and finely scented.

Tausendschon-Varying shades, from a delicate flushed white to a deep rosy carmine.

\section{Other Varieties of Roses That We Grow}

ANNA DE DIESBACH-Lovely shell pink.

BABY RAMBLER-Dwarf crimson rambler, with the same brilliant color.

BLUE RAMBLER - The nearest approach to a blue rose.

BLUMENSCHMIDT-Yellow, tinged pink.

CAPTAIN CHRISTY-Delicate flesh-pink.

CATHERINE MERMET-Light rosy flesh.

CHAMPION OF THE WORLD-Very deep pink. 
CHEROKEE-White flowers in spring.

CHRISTINE DE NOUE-Rich red, shaded maroon.

CLIMBING AMERICAN BEAUTY-Same as its namesake in size, fragrance and color.

CLIMBING BRIDESMAID-Like Bridesmaid.

CLIMBING DEVONIENSIS-Creamy white, yellow center.

DUCHESS OF ALBANY-Two shades darker than LaFrance.

EDWARD MAWLEY - Deep velvety crimson.

ETOILE DE LYON-Golden yellow。

EXCELSA-As fine a grower as Dorothy Perkins, flowers a rich deep red.

FLOWER OF FAIREIELD-The everblooming erimson rambler. FREIHERR VON MARSCHALL-Deep red.

GENERAL JACQUENINOT-Brilliant scarlet erimson.

GENERAL MACARTHUR-Crimson-scarlet.

GOLDEN GATE-Creamy white, tinted soft yellow at base.

HOOSIER BEAUTY-Glowing crimson.

KILLARNEY BRILLIANT-Sparkling pink.

LAMARQUE-Climber, pure white.

LAURENT CARLE-Brilliant velvety carmine.

MME. CAROLINE TESTOUT-Brilliant satiny rose, deepening at the center.

MAL. DE WATTVEILLE-Creamy white, edged carmine.

MME. F. KRUGER-Coppery yellow, tinged pink.

MME. MASSON-Intense red, with erimson hue.

MLLE. CECILE BRUNNER-Rosy Pink on rich ereamy white, shaded light salmon.

MARECHAL NIEL-Golden yellow blossoms in rich profusion, with a fragrance peculiar to Marechal Niel alone.

MARSHALL P. WILDER-Deep rich red.

MARY WASHINGTON-Pure white.

MEMORIAL ROSE-Shiny white bright golden center.

MILADY - Rich searlet.

MRS. AARON WARD-Indian yellow, shading to lemon-cream.

MRS. B. R. CANT-Bright, clear rose pink.

MY MARYLAND - Salmon-pink of soft and pleasing shade.

OPHELIA-Special, brilliant salmon-flesh.

PAPA GONTIER-Dark, passing to glowing crimson.

PEARL VON GODESBERG-Canary yellow of a rich shade.

PILLAR OF GOLD-Apricot-yellow flushed with coppery pink and old-gold.

PRESIDENT TAFT-Shining shell pink.

PRINCE CAMILLE DE ROHAN-Rich velvety erimson, passing to maroon.

QUEEN OF PRAIRIE-Bright rosy red.

RADIANCE-Brilliant rosy carmine, shaded with rich opaline pink tints in the open flower.

REINE MARIE HENRIETTE-Rich, brilliant erimson elimber.

RHEA REID-Red.

RICHMIOND-Scarlet-crimson of brilliant hue.

RUGOSA ALBA-White fragrant flowers, followed by bright attractive berries.

RUGOSA RUBRA-Same as above, except that the flowers are crimson.

SAFRANO-Bright apricot-yellow.

SOUVENIR DE LA MALMAISON-Flesh-pink.

SOUVENIR DE PRESIDENT CARNOT-Delicate flesh white. SUNBURST-Orange-copper or golden orange and golden yellow all intense shades giving an extremely brilliant effect.

THE BRIDE-Pure white under glass, but takes on a delicate pink tinge out of doors.

ULRICH BRUNNER-Brilliant cherry-red.

WHITE DOROTHY PERKINS-Same as the well-known Dorothy Perkins except that it is pure white.

WHITE KILLARNEY - Same as its parent Killarney, except that it is pure white.

WHITE LA FRANCE-Silvery white with very delicate pink shadings.

WHITE MAMAN COCHET-Pure waxy white under glass, faint pink flush out of doors.

WILLIAM ALLEN-RICHARDSON-Deep orange yellow, coppery yellow center.

WILLIAM R. SMITH-Creamy white with shadings of pink.

Prices For Roses

\begin{tabular}{|c|c|c|c|c|}
\hline & & Each & Dozen & 100 \\
\hline Extra & Strong &.$\$ 1.00$ & $\$ 10.00$ & $\$ 80.00$ \\
\hline No. 1 & & .. $\quad .75$ & 7.50 & 60.00 \\
\hline No. 2 & & .. .50 & 5.00 & 40.00 \\
\hline Specia & varietie & .. 1.25 & 12.50 & 100.00 \\
\hline
\end{tabular}





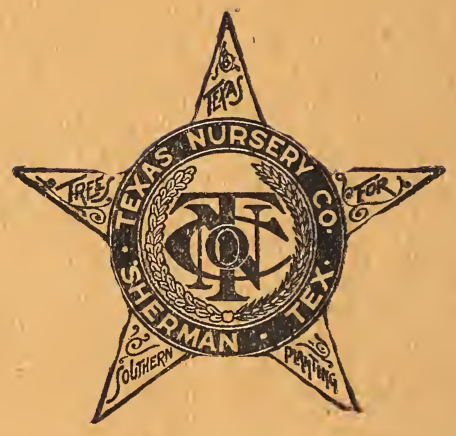

DUNETT PRINTING CO., PARIS, TEXAS. 